\title{
Inventory, Marketing and Markups of Exporters: The Case of Spinning, Weaving and Finishing Textile Sector of Pakistan
}

\author{
Imtiaz Ahmad* and Zafar Mahmood**
}

\begin{abstract}
This paper studies the impact of inventory-intensity, marketing-intensity and firm size on the markups of exporting firms. We used audited financial statement data of publicly listed companies in the spinning, weaving and finishing industry within the textiles sector of Pakistan. We document five observations: 1) average markup of exporters is relatively higher than non-exporters; 2) there is higher dispersion in markups of non-exporters relative to exporters; 3) large firms have relatively higher markup and marketing-intensity; 4) firms which have higher marketing- and inventory-intensity also have higher markups; and 5) exporters have relatively higher markup elasticity with respect to marketing-intensity, inventory-intensity and growth in inventory-intensity.
\end{abstract}

Keywords: Markups, inventory intensity, marketing intensity, firm size, Pakistan.

JEL classification: F14, L11, L25.

\section{Introduction}

The analysis of markup determinants has a long tradition in international trade and industrial organization. The changes in firms' market power are typically measured by firms' markups. Previous studies within the international trade literature that incorporate features of monopolistic competition (e.g., increasing returns and heterogeneous firms) has recently included variable markups to create a clearer picture of international trade (Melitz and Ottaviano, 2008; Edmond, Midrigan \& Xu, 2015; Melitz, 2018). The models which have utilized constant markup ${ }^{1}$ are useful for explaining trade at extensive margins (i.e., which products are exported where), whereas, models that use variable markups are helpful in explaining trade at intensive margins (i.e., relative market shares of

\footnotetext{
* PhD Scholar at Department of Economics, National University of Sciences and Technology, Islamabad, Pakistan; Email: imtiaz.ahmad@s3h.nust.edu.pk

** Head of Development Studies Department, National University of Sciences and Technology, Islamabad, Pakistan.

${ }^{1}$ See Melitz and Redding (2014) for a survey.
} 
exported products). Therefore, models that include both factors are relatively better in explaining margins, as international trade fluctuates to adjust to a number of factors such as competition, trade liberalization and other policy interventions.

Most theoretical and empirical studies focus on market size and trade liberalization as the two key factors that increase productivity and decrease markups via increase in competition. However, firm-specific factors are not given appropriate share of attention in the international trade literature on markups. In this study, rather than focusing on demandside factors directly, we analyse firm-specific factors that reflect the uncertainties of demand and demand creation features of a monopolistic firm to explain markup variations.

The literature providing explanations of firms' heterogeneity and international trade has evolved into three key parts: 1) a strand that primarily considers productivity and size (Melitz, 2003; Bernard \& Jensen, 2004; Jean, 2002; Bernard, Eaton, Jensen \& Kortum, 2003); 2) a strand that incorporates variables markups (Melitz \& Ottaviano, 2008; Feenstra \& Weinstein, 2010; Edmond, Midrigan \& Xu, 2015); and 3) a strand that focuses on the impact of uncertainties (Feng, Li \& Swenson, 2017; Handley, 2014; Lewis, 2014).

The first strand of literature primarily emphasizes firms' heterogeneity in productivity and size, which is symmetrically related to export participation, with exporters being larger and more productive relative to non-exporters within an industry. The theoretical approach of this strand of literature considers firms' price as constant markup over marginal cost (Melitz, 2003). Markups are considered as constant, though prices are tied to marginal cost of production, but the markup variations caused by factors such as demand creation, differentiation and uncertainties are ignored.

The second strand of literature incorporates variable markups in explaining firms' heterogeneity and international trade. The early empirical literature combined variable markups with differentiated products to estimate aggregated demand and supply for products (Berry, Levinsohn \& Pakes, 1995; Goldberg, 1995). Feenstra and Weinstein (2010) estimated the impact of globalization on welfare via variations in markups that arise because of globalization. 
The theoretical literature in international trade incorporates variable markups by combining the standard Constant Elasticity of Substitution (CES) demand system and imperfect competition, such as monopolistic competition with a small number of firms (Atkeson \& Burstein, 2008) and large number of firms (Edmond et al., 2015). Melitz and Ottaviano (2008), an extension of Melitz (2003), have formally modelled variable markups along with productivity that respond to trade liberalization. All three frameworks predict that more productive firms have a larger market share and higher markups, and international trade increases competition and reduce markups. These pro-competitive gains from trade, caused by variable markups, whether under CES or non-CES demand systems, have increasingly become the focus of the recent literature in international trade.

The existing empirical literature that incorporates variable markups supports the pro-competitive effects of trade, as demonstrated in the first strand of literature mentioned above (i.e., trade has twofold impact on a particular industry). At the firm level, trade liberalization increases competition and decreases the market power of non-exporters, compelling firms to reduce markups. At the industry level, trade liberalization affects the markup distribution and reduces dispersion (Restuccia \& Rogerson, 2008; Hsieh \& Klenow, 2009; Lu \& Yu, 2015). Contrary to these studies, there is also the possibility of negative pro-competitive effects causing labor reallocation towards more productive exporting firms, which internalizes the lower trade cost and increases markup (Edmond et al., 2015; Arkolakis, Costinot, Donaldson \& Rodríguez-Clare, 2015).

The third strand of literature increases the focus on the impact of uncertainties on trade (Feng et al., 2017; Handley, 2014; Handley \& Limao, 2015; Lewis, 2014; Nguyen, 2012; Novy \& Taylor, 2014). These studies suggest that uncertainties decrease firm entry into the export market and decrease firm level exports, with the exception of Lewis (2014), who found that firms export more when they face inflation uncertainties.

Firms keep the finished output or intermediates as inventory to mitigate demand and supply-side uncertainties. The higher the stock of finished and intermediate goods, the better the firm is able to mitigate demand and supply-side uncertainties. Inventories are particularly important for exporting firms since they have to face more uncertainties relative to domestic firms. Exporting firms must deal with multiple factors affecting demand for their products in the destination markets. There is also cost attached to output and price adjustments that a firm makes to 
account for cases in which their substantial growth in inventories occur in times of low demand, and also the greater opportunity costs of being out of stock. Although there is much literature on the issue of inventory adjustment under uncertainties (Novy and Taylor 2014; Alessandria, Kaboski \& Midrigan, 2013; Tamegawa 2014), the literature on variable markups have little to say about the role of inventories in affecting a firm's markup and exports.

Firms under monopolistic competition, always and everywhere, are more interested in marginal revenue product than the value of marginal product from the inputs they employ. In simple words, firms are more concerned about generating additional revenue from the input they employ than they are about additional physical output in money terms. In this setting, firms are interested in the most profitable adjustments in overall expenditures, and therefore are bound to consider selling, distribution and marketing expenditure, the purpose of which is not to increase production but to get maximum sales revenue. Such expenditures are particularly relevant under monopolistic competition and serve as a tool of demand creation. However, the demand creation feature of monopolistic firms has remained completely disregarded in the literature on international trade and markups. Consequently, pricing and output decisions of firms have been studied in isolation from factors that can potentially affect the position or alter the shape of demand curve.

Our paper adds to the recent literature on variable markups and uncertainties. Our goal is to provide new empirical facts about the role of inventories and demand creation activities in explaining the variable markups of exporting firms. We choose a narrow industry within the textiles sector (spinning, weaving and finishing), which is a key exporting industry of Pakistan, and use audited financial statements of publicly listed companies for the period 2010 to 2015. The data is published in the form of annual financial statements by the State Bank of Pakistan. Our sample contains 91 firms, of which 25 are non-exporters and 66 are exporting firms. Our key findings, as we discuss in more detail below, are: 1) even in this narrowly defined industry the dispersion in markups of non-exporters is relatively higher than exporters, but mean markups of exporst are higher for exporters; 2) larger firms have higher markups and they market their products extensively; 3) firms which have higher inventory-intensity have higher markups but growth in inventor-intensity decreases markup; and 4) the magnitude of the impact of marketing-intensity and growth in inventory-intensity is higher in the case of exporters. 


\section{Markup Dispersion across Exporting and Non-Exporting Firms}

We define markup as a percentage difference between selling price and cost per unit ${ }^{2}$. We start by reporting the distribution of markup of firms by their exporting status. The markups reported in Table 1 are averaged over a five-year period (2010-2015) and the mean markup for the whole sample is 11.78 percent. The exporting firms have a higher markup (12.31 percent) compared to non-exporters (9.11 percent). The dispersion in markups is as follows: $90-10$ percentile ratio and $75-25$ percentile ratio is less for exporters compared to non-exporters. The coefficient of variation of markups is 45.47 for exporters and 62.82 for non-exporters. We have considered relatively higher average markup and lower dispersion of exporters as our first key finding.

The relatively higher markups of exporting firms can be associated with higher quality and lower average cost of production. However, it is uncertain whether exporters charge different prices for export sales relative to local shares. On the other hand, Figure 1 shows the positive correlation between markups and export orientation, measured as ratio of exports in total sales. Even within exporters, markups marginally increase with the level of export orientation.

The relatively lower dispersion in average markups of exporters, as the literature suggests, indicates that they are more competitive relative to non-exporting firms (Melitz \& Ottaviano, 2008). On the other hand, the higher average markup is associated with larger size, inventory- and marketing-intensity of exporters, as we discuss in more detail below.

\footnotetext{
${ }^{2}$ Unlike most of the studies that use survey data, the issues of overstatement or understatement are negligible in the case of data based on audited financial statements. Therefore, instead of indirectly estimating the markups based on production data under a number of assumptions, as in De Loecker and Warzynski (2012) and other studies, we measure markups directly based on data from audited financial statements. For details on the measure of markup, see appendix.
} 
Table 1: Dispersion in Average Markup* by Exporters and Non-Exporters

\begin{tabular}{lccc}
\hline & Whole Sample & Non-Exporters & Exporters \\
\hline Min & 0.62 & 0.62 & 0.66 \\
P5 & 2.09 & 0.79 & 2.37 \\
P10 & 2.84 & 1.78 & 4.33 \\
P25 & 6.83 & 3.23 & 8.23 \\
P50 & 12.45 & 8.80 & 12.94 \\
P75 & 15.72 & 14.74 & 16.25 \\
P90 & 20.06 & 15.95 & 20.40 \\
Max & 29.78 & 20.15 & 29.78 \\
Mean & 11.78 & 9.11 & 12.31 \\
Std. dev & 6.55 & 5.72 & 5.59 \\
P90/P10 & 7.07 & 9.47 & 4.72 \\
P75-/P25 & 2.30 & 4.19 & 1.97 \\
Coef. Var. & 55.59 & 62.82 & 45.47 \\
Observations & 91 & 25 & 66 \\
\hline
\end{tabular}

*Markups are averaged over 5 year

Source: Authors' calculations.

Figure 1: Markups and Export Orientation

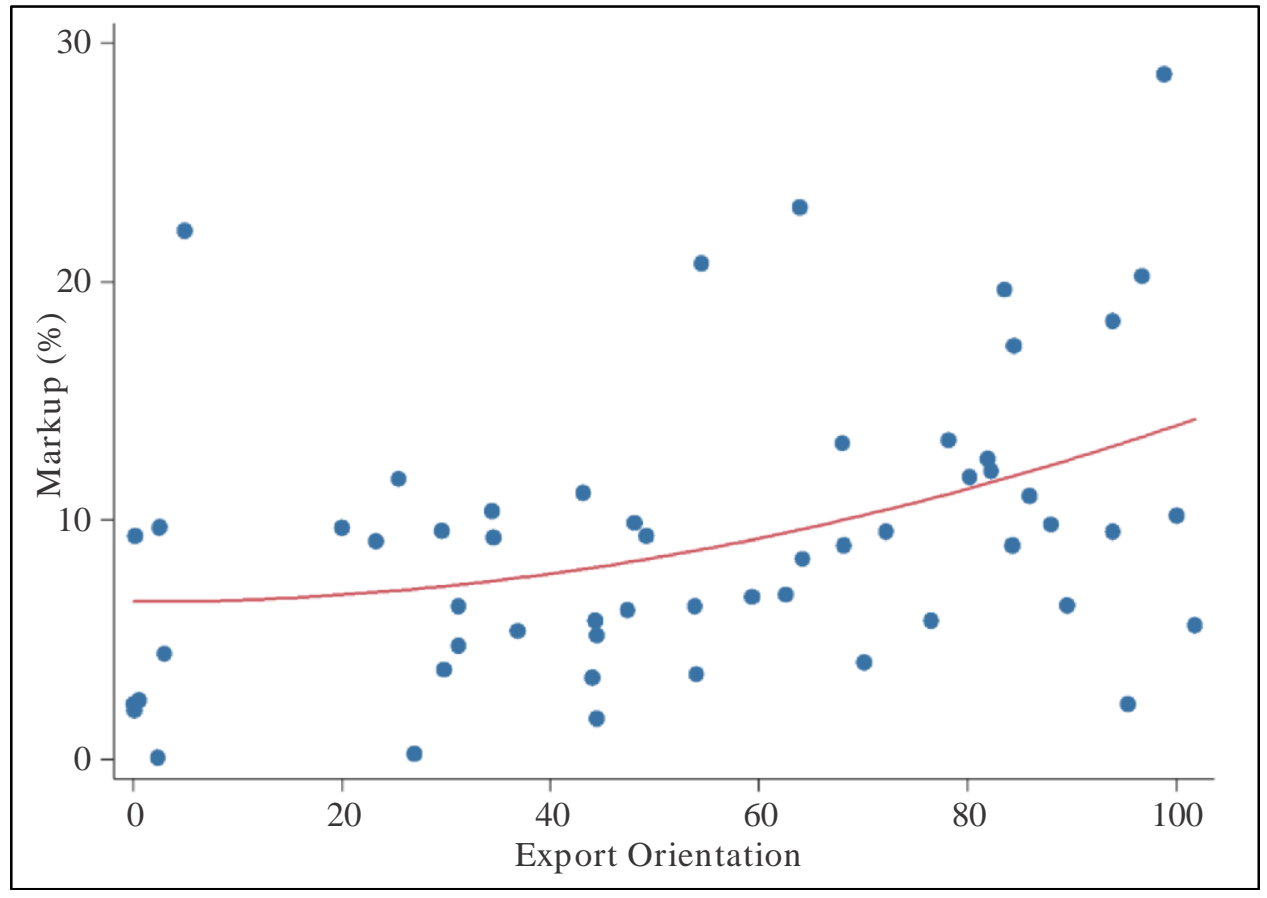

Source: Authors' calculations. 


\section{Markups, Firm Size and Marketing-Intensity}

The literature also documents how markups are related to key firm characteristics. One of the key predictions in these models is that more productive firms have higher market share and are larger in size (Melitz, 2003; Bernard \& Jensen, 2004; Melitz \& Ottaviano, 2008). Motivated by these arguments, we focus on the relationship between markups and firm size. We take total assets, including total current and fixed assets, and use them as a proxy for firm size.

Figure 2: Markups and Firm Size

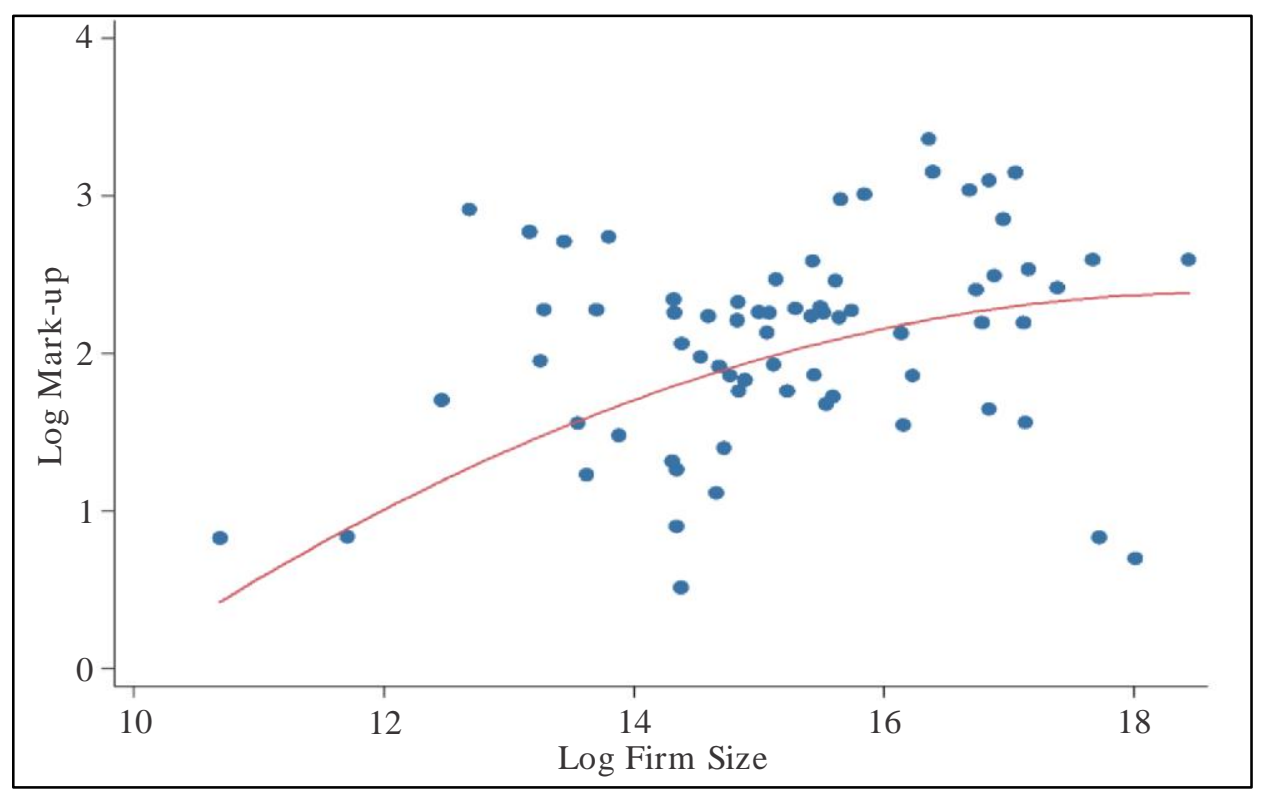

Source: Authors' calculations.

Figure 2 shows the relationship between markups and firm size. Overlaid on the scatter plot is a curve of quadratic fit. The markups are positively correlated with firm size. The elasticity of markups with respect to firm size is 0.14 (see Table 2, between effects), which is statistically significant. Atkin, Chaudhry, Chaudhry, Khandelwal \& Verhoogen (2015) have also analysed markups in Pakistan's soccer-ball producers and have observed positive correlation between markup and firm size with an elasticity of 0.31 . The theoretical literature that models firms as heterogeneous along a single dimension (e.g., productivity) predicts that more productive firms are larger in equilibrium - thus firm size is a proxy for a firm's entrepreneurial ability and productivity. 
There must be fine line drawn between cost incurred for distribution, advertisement or marketing of products and production costs, especially under monopolistic competition. The former is completely ignored in the existing literature on international trade, firm heterogeneity and on variable markups. Attention has been confined only to price and quantity adjustments. Consequently, the firms' cost curve only comprises outlays for producing products to meet demand, and not to create demand.

Selling cost includes outlays for the marketing of varieties, margins granted to dealers/retailers, shelf costs, demonstrations of new goods, etc. There is no need for such costs if we assume that wants are constant and buyers have perfect knowledge. Otherwise, these costs can potentially affect the demand and, therefore, prices and profits. Firms which have different varieties, continue upgrading quality or possess other characteristics with respect to their products are likely to have higher costs of distribution and advertisement, due to higher salaries of salesmen, higher margins of dealers, window displays, or simply increased efforts to sell new products. Intensive marketing of products also indicates differentiation and demand creation on the part of firms. Moreover, quality competition is stimulated by informing a large number of potential consumers about the quality changes in the product, or even of existing qualities of which they may not be aware. Demand is satisfied more effectively if consumers are aware of the characteristics of the product. Secondly, marketing affects demand by altering the desires of consumers. We measure marketing intensity as expenditures on distribution, advertisement and marketing expenses related to sales as a ratio of costs of sales.

\section{Figure 3:}

Markups and Marketing-Intensity

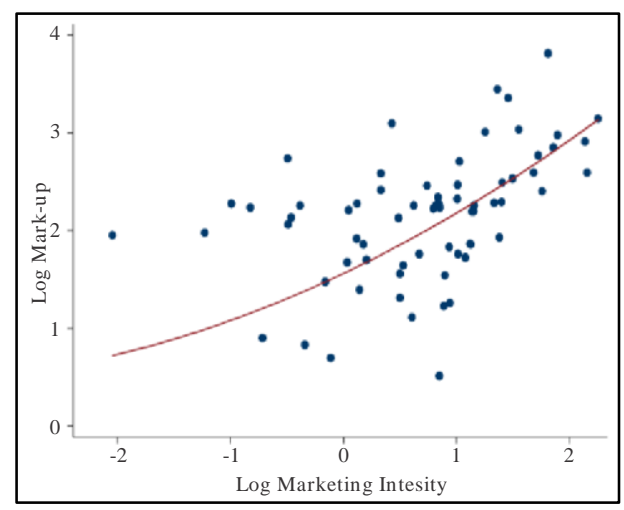

Marketing-Intensity and Firm Size

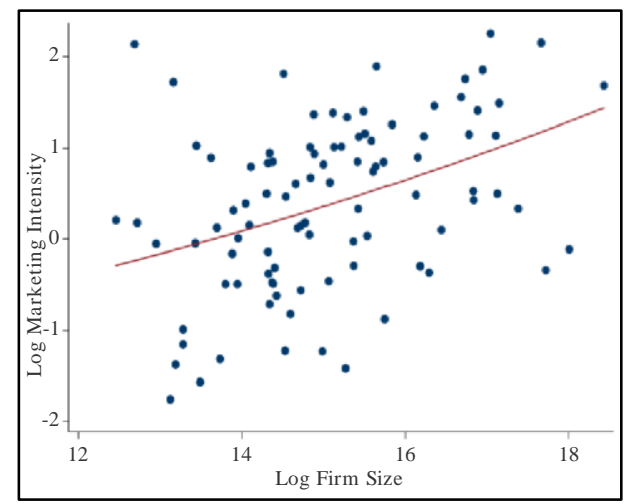

Source: Authors' calculations. 
The left panel of figure 3 shows the relationship between markups and marketing intensity of firms. Firms which have higher marketing intensity have relatively higher markups. As discussed ealier, firms which spend more on marketing activity have higher markups. Such firms are likely to have higher quality, rapid changes and upgrades of products, or advanced and costly distribution channels. Marketing intensity is also correlated with firm size (see right panel of Figure 3) which indicates that large firms are better positioned to market their products.

\section{Markups and Inventories}

Inventories are an inevitable consequence of demand and supplyside uncertainties. It follows from the distinction between marginal revenue product and the value of marginal product that a firm's output decisions are more influenced by the marginal revenue product. The inventories are kept either in anticipation of higher marginal revenue product, via mitigating uncertainties, or they simply demonstrate the gap between demand and supply, which includes: 1) unsold output that becomes part of inventory, 2) output that is produced for later sales, or 3) the work-in-progress output and inputs, like materials and overheads.

\section{Figure 4:}

\section{Markups and Inventory-Intensity}

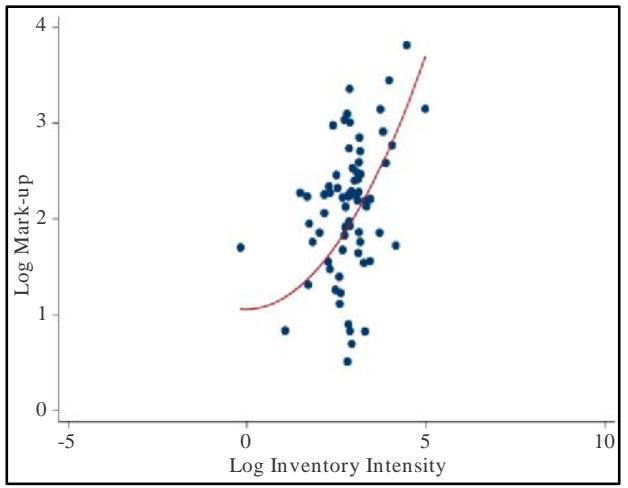

Markups and Growth in Inventor-

Intensity

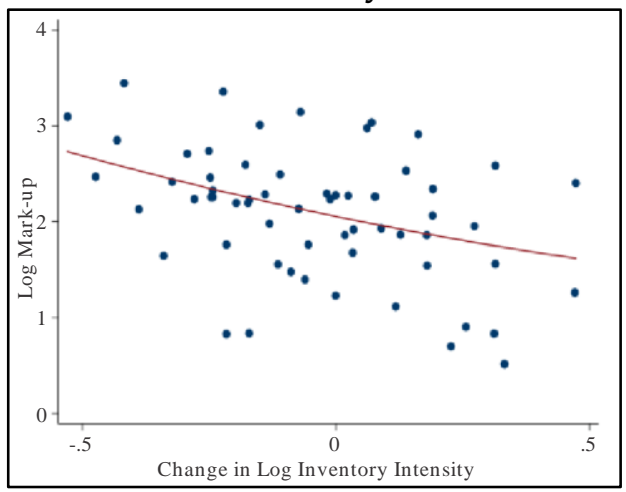

Source: Authors' calculations.

Keeping goods in inventory can affect markups in many ways. Firstly, keeping inventory is costly. Secondly, inventories, if kept at an appropriate amount, may increase marginal revenue product via reducing losses in case of demand- and supply-side uncertainties. The literature linking markups, inventories and trade is scant and says little regarding the direction of the relationship. However, inventories really become 
important in terms of their impact on a firm's markups and exports when they compel firms to make output and price adjustments.

The right panel of Figure 4 shows the ratio inventories measured at cost to the total cost of sales, which indicates the amount of output remaining unsold or kept for sales in a later time period relative to output which is sold. We call this the inventory-intensity of the firm. The positive relationship between inventory-intensity and markups shows that higher inventories put firms in a better position to respond to demand- and supply-side uncertainties. The left panel of Figure 4 shows the relationship between markups and growth in inventory-intensity. Positive growth in inventory-intensity relative to sales is associated with lower markups and decrease in growth is associated with higher markups.

What causes the negative relationship between markups and growth in inventory-intensity? Growth in inventory-intensity can be a result of an increase in output that is unsold and/or an increase in unused material or unfinished output relative to sales. There are costs involved in maintaining these inventories and firms incur these costs to avoid losses in the case of demand- and supply-side uncertainties. However, significant growth in the inventory-intensity is an indicator of deeper issues, such as an increase in competition, demand, or supply-side shocks. The negative relationship between markups and inventory-intensity also points to the presence of adjustment costs (Kryvtsov \& Midrigan, 2012). In other words, a substantial increase in inventories relative to sales compels firms to adjust output or prices and these adjustments are not costless.

\section{Markup Elasticities across Times and Firms}

We estimate the within-effects and between-effects model to measure the markup elasticities with respect to size, marketing-intensity, inventory-intensity and growth in inventory-intensity.

$$
\operatorname{Markup}_{i t}=\beta_{0}+\beta_{1} \text { Size }_{i t}+\beta_{2} \operatorname{Inv}_{i t}+\beta_{3} \Delta \operatorname{Inv} v_{i t}+\beta_{4} M r k t_{i t}+e_{i t}
$$

We report different specifications of both within-effects and between-effects in order to keep in check the effect of possible relationships between size, inventory-intensity and marketing-intensity. Equations (1)(4) in Table 2 estimate the markup elasticities over time with respect to a firm's size, inventory-intensity and marketing-intensity. The increase in size of a firm over time is negatively correlated with markups which may indicate the impact of an increase in the average cost of a firm as its size 
increases. The elasticity of markup and a firm's size is strongly negative for exporters relative to the whole sample.

Firstly, an increase in marketing- or inventory-intensity over time does not affect the markups of exporters, but the relationship is positive and significant in the whole sample. Secondly, the impact of increase in size over time is higher in the case of exporters and size is not strongly correlated with marketing- and inventory-intensity as firm size does not change much and remains significant after including inventory-intensity and marketingintensity variables. On the other hand, for the overall sample, inventoryintensity and marketing-intensities correlate with firm size.

Equations (5)-(10) in Table 2 estimate the markup elasticities with respect to size across firms. It is reassuring that larger firms have higher markups and the elasticity coefficients are also significant both for the whole sample and exporters. Furthermore, the markup elasticity with respect to size is relatively higher for exporters. The elasticity coefficients of markups with respect to inventory-intensity and marketing-intensity are also positive and highly significant. However, the positive correlation between size, inventoryintensity and marketing-intensity decreases the elasticity coefficient with respect to firm size in both whole sample and exporter equation.

\section{Table 2: Markup Elasticities}

\begin{tabular}{|c|c|c|c|c|c|c|c|c|c|c|}
\hline & \multicolumn{4}{|c|}{ Within Effects } & \multicolumn{6}{|c|}{ Between Effects* } \\
\hline & \multicolumn{2}{|c|}{ Whole Sample } & \multicolumn{2}{|c|}{ Exporters } & \multicolumn{3}{|c|}{ Whole Sample } & \multicolumn{3}{|c|}{ Exporters } \\
\hline & (1) & (2) & (3) & (4) & (5) & (6) & $(7)$ & (8) & (9) & (10) \\
\hline Log Size & $\begin{array}{l}-0.34^{*} \\
(0.17)\end{array}$ & $\begin{array}{l}-0.42^{* *} \\
(0.20)\end{array}$ & $\begin{array}{l}-0.51^{* * *} \\
(0.16)\end{array}$ & $\begin{array}{l}-0.50^{* *} \\
(0.21)\end{array}$ & $\begin{array}{l}0.21^{* * *} \\
(0.04)\end{array}$ & $\begin{array}{l}0.04 \\
(0.05)\end{array}$ & $\begin{array}{l}0.14^{*} \\
(0.07)\end{array}$ & $\begin{array}{l}0.19^{* * *} \\
(0.05)\end{array}$ & $\begin{array}{l}0.06 \\
(.05)\end{array}$ & $\begin{array}{l}0.21^{* * *} \\
(.08)\end{array}$ \\
\hline Log Inv. Intensity & & $\begin{array}{l}0.21^{* * *} \\
(0.08)\end{array}$ & & $\begin{array}{l}0.11 \\
(0.07)\end{array}$ & & $\begin{array}{l}0.33^{* * *} \\
(.09)\end{array}$ & & & $\begin{array}{l}0.24^{* *} \\
(.10)\end{array}$ & \\
\hline $\begin{array}{l}\Delta \text { Log Inv. } \\
\text { Intensity }\end{array}$ & & & & & & & $\begin{array}{l}-0.61^{* *} \\
(0.27)\end{array}$ & & & $\begin{array}{l}-0.67^{* *} \\
(.32)\end{array}$ \\
\hline $\begin{array}{l}\text { Log Mrkt. } \\
\text { Intensity }\end{array}$ & & $\begin{array}{l}0.23^{* *} \\
(0.10)\end{array}$ & & $\begin{array}{l}0.11 \\
(0.19)\end{array}$ & & $\begin{array}{l}0.17^{* * *} \\
(0.06)\end{array}$ & $\begin{array}{l}0.33^{* * *} \\
(0.09)\end{array}$ & & $\begin{array}{l}0.33^{* * *} \\
(0.08)\end{array}$ & $\begin{array}{l}0.57^{* * *} \\
(.13)\end{array}$ \\
\hline Constant & $\begin{array}{l}7.33^{* * *} \\
(2.56)\end{array}$ & $\begin{array}{l}7.81^{* * *} \\
(2.94)\end{array}$ & $\begin{array}{l}10.04^{* * *} \\
(2.49)\end{array}$ & $\begin{array}{l}9.47^{* * *} \\
(3.10)\end{array}$ & $\begin{array}{l}-0.92 \\
(0.66)\end{array}$ & $\begin{array}{l}0.65 \\
(0.07)\end{array}$ & $\begin{array}{l}-0.32 \\
(1.13)\end{array}$ & $\begin{array}{l}-0.61 \\
(0.75)\end{array}$ & $\begin{array}{l}0.58 \\
(0.69)\end{array}$ & $\begin{array}{l}-1.8 \\
(1.17)\end{array}$ \\
\hline R-squa & 0.04 & 0.07 & 0.07 & 0.03 & 0.17 & 0.34 & 0.27 & 0.13 & 0.38 & 0.40 \\
\hline Observations & 558 & 552 & 425 & 429 & 570 & 552 & 91 & 433 & 499 & \\
\hline
\end{tabular}

Notes: Table report elasticities of markups separately for whole sample and exporters. The between effects equations with change in log of inventory intensity is estimated with 2015 data only because data on inventories are available only for 2014 and 2015. Robust standard errors are reported. Significance ${ }^{*} .10 * * .05 * * * .01$.

Source: Authors' calculations. 
The coefficient of firm size in equation (9) is biased downwards because of positive correlation between firm size and growth in inventories. Equation (10), with growth in inventory-intensity, significantly improves the results and removes the bias. When controlling for export-intensity, as measured by export sales as a ratio of total sales, it does not significantly alter the markup elasticities of firm size, inventory- or marketing-intensities (See Table 2A). The negative relationship between growth in inventoryintensity and markup shows the presence of cost adjustments which have a significant negative impact on markups. Also, the markup elasticity with respect to marketing-intensity and growth in inventory-intensity is relatively higher for exporters, indicating the higher costs of adjustments that exporters have to face because of production and demand-side uncertainties and the greater positive impact of marketing activities.

Table 2A: Markup Elasticities

\begin{tabular}{lcc}
\hline Variables & Within Effects & Between Effects \\
\hline Log Size & $-0.496^{* *}$ & $0.217^{* * *}$ \\
& $(0.205)$ & $(0.0779)$ \\
Log Inv. Intensity & 0.100 & \\
& $(0.0729)$ & \\
Log Mrkt. Intensity & 0.145 & $0.509^{* * *}$ \\
& $(0.188)$ & $(0.181)$ \\
$\Delta$ Log Inv. Intensity & & $-0.664^{* *}$ \\
& & $(0.325)$ \\
Log Export share & -0.0564 & 0.0382 \\
& $(0.0831)$ & $(0.0858)$ \\
Constant & $9.607^{* * *}$ & -1.969 \\
& $(2.974)$ & $(1.241)$ \\
Observations & 429 & 58 \\
R-squared & 0.050 & 0.409 \\
Number of orgen & 95 & 58 \\
\hline Note: Robust stand
\end{tabular}

Note: Robust standard errors in parentheses

${ }^{* * *} \mathrm{p}<0.01,{ }^{* *} \mathrm{p}<0.05,{ }^{*} \mathrm{p}<0.1$.

Source: Authors' calculations.

\section{Conclusions}

In this paper, we have documented the dispersion in markups of exporters and non-exporters in the spinning, weaving and finishing industry within the textiles sector of Pakistan. Our findings are based on audited financial statements of publicly listed companies. Although, focused in this specific setting, our findings have important implications for the ongoing debate on variable markups and how to model it. 
In relation to the literature on firm heterogeneity and variable markups, our main findings are: 1) aside from firm size, demand creation activities of firms also affect markups; 2) exporting firms are more competitive and have higher average markups which slightly increase with the level of export orientation; 3) growth in inventory-intensity has a negative impact on markups, which is relatively higher in terms of magnitude in the case of exporters; and, 4) the elasticity of markup with respect to size, marketing-intensity and growth in inventory-intensity is relatively higher for exporting firms.

Our findings suggest an important link between markups, inventories, and the demand creation feature of firms. It would be interesting to investigate whether these patterns hold in other settings. Even without assuming that these patterns would generalize, there is significant literature on uncertainties that indicate that firms adjust to uncertainties in a number of ways and the immediate impact of uncertainties is on inventories and output decisions. However, this issue is not wellrepresented in the literature on variable markups. Our findings also suggest that theoretical literature should account for the positive relationship between markups and selling and advertising costs. 


\section{References}

Alessandria, G., Kaboski, J., \& Midrigan, V. (2013). Trade wedges, inventories, and international business cycles. Journal of Monetary Economics, 60(1), 1-20.

Arkolakis, C., Costinot, A., Donaldson, D., \& Rodríguez-Clare, A. (2015). The elusive pro-competitive effects of trade(No. w21370). National Bureau of Economic Research.

Atkeson, A., \& Burstein, A. (2008). Pricing-to-market, trade costs, and international relative prices. American Economic Review, 98(5), 19982031.

Atkin, D., Chaudhry, A., Chaudhry, S., Khandelwal, A. K., \& Verhoogen, E. (2015). Markup and cost dispersion across firms: Direct evidence from producer surveys in Pakistan. American Economic Review, 105(5), 537-44.

Bernard, A. B., Eaton, J., Jensen, J. B., \& Kortum, S. (2003). Plants and productivity in international trade. American Economic Review, 93(4), 1268-1290.

Bernard, A. B., \& Jensen, J. B. (2004). Entry, expansion, and intensity in the US export boom, 1987-1992. Review of International Economics, 12(4), 662-675.

Berry, S., Levinsohn, J., \& Pakes, A. (1995). Automobile prices in market equilibrium. Econometrica: Journal of the Econometric Society, 841-890.

De Loecker, J., \& Warzynski, F. (2012). Markups and firm-level export status. American Economic Review, 102(6), 2437-71.

Edmond, C., Midrigan, V., \& Xu, D. Y. (2015). Competition, markups, and the gains from international trade. American Economic Review, 105(10), 3183-3221.

Feenstra, R. C., \& Weinstein, D. E. (2010). Globalization, markups and US welfare (No. w15749). National Bureau of Economic Research.

Feng, L., Li, Z., \& Swenson, D. L. (2017). Trade policy uncertainty and exports: Evidence from China's WTO accession. Journal of International Economics, 106, 20-36. 
Goldberg, P. K. (1995). Product differentiation and oligopoly in international markets: The case of the US automobile industry. Econometrica: Journal of the Econometric Society, 891-951.

Handley, K. (2014). Exporting under trade policy uncertainty: Theory and evidence. Journal of international Economics, 94(1), 50-66.

Handley, K., \& Limao, N. (2015). Trade and investment under policy uncertainty: theory and firm evidence. American Economic Journal: Economic Policy, 7(4), 189-222.

Hsieh, C. T., \& Klenow, P. J. (2009). Misallocation and manufacturing TFP in China and India. The Quarterly Journal of Economics, 124(4), 14031448 .

Jean, S. (2002). International trade and firms' heterogeneity under monopolistic competition. Open Economies Review, 13(3), 291-311.

Kryvtsov, O., \& Midrigan, V. (2012). Inventories, markups, and real rigidities in menu cost models. Review of Economic Studies, 80(1), 249-276.

Lewis, L. T. (2014). Exports versus multinational production under nominal uncertainty. Journal of International Economics, 94(2), 371-386.

Lu, Y., \& Yu, L. (2015). Trade liberalization and markup dispersion: evidence from China's WTO accession. American Economic Journal: Applied Economics, 7(4), 221-53.

Melitz, M. J. (2003). The impact of trade on intra-industry reallocations and aggregate industry productivity. Econometrica, 71(6), 1695-1725.

Melitz, M. J. (2018). Competitive effects of trade: theory and measurement. Review of World Economics, 154(1), 1-13.

Melitz, M. J., \& Ottaviano, G. I. (2008). Market size, trade, and productivity. The Review of Economic Studies, 75(1), 295-316.

Melitz, M. J., \& Redding, S. J. (2014). Heterogeneous firms and trade. In Handbook of International Economics, Vol. 4, pp. 1-54.

Nguyen, D. X. (2012). Demand uncertainty: Exporting delays and exporting failures. Journal of International Economics, 86(2), 336-344. 
Novy, D., \& Taylor, A. M. (2014). Trade and Uncertainty (No. w19941). National Bureau of Economic Research.

Restuccia, D., \& Rogerson, R. (2008). Policy distortions and aggregate productivity with heterogeneous establishments. Review of Economic Dynamics, 11(4), 707-720.

Tamegawa, K. (2014). Demand uncertainty, inventory and business cycles. Journal of Business Economics and Management, 15(4), 664-683. 


\section{Appendix}

The firm's profit is defined as the difference between total revenues and total costs i.e.

$$
\pi_{i}=T R_{i}-T C_{i}=p_{i} q_{i}-c_{i} q_{i}-f_{i}
$$

where $p_{i}$ is unit price, $q_{i}$ is quantity, $c_{i}$ is cost per unit and $f_{i}$ is fixed cost. The markup of firm $i$ is defined as

$$
p_{i}=\left(1+\mu_{i}\right) c_{i}
$$

where $\mu_{i}$ represents firms markup over marginal cost

$$
\mu_{i}=\frac{\left(p_{i}-c_{i}\right)}{c_{i}}
$$

Markup can also be represented in terms of total revenues and variables costs

$$
\mu_{i}=\frac{\left(p_{i}-c_{i}\right) q_{i}}{c_{i} q_{i}}=\frac{T R_{i}-V C_{i}}{V C_{i}}
$$

